\title{
Reassembling Insecurity: The Power of Materiality
}

\author{
Ana Ivasiuc
}

Between 160.000 and 180.000 Roma and Sinti live in Italy, amounting to less than $0.3 \%$ of the population. ${ }^{1}$ Notwithstanding this insignificant percentage, in the spring of 2008 , following an episode of moral panic around a murder perpetrated by a Romanian citizen of Roma background in Rome, the Italian government declared a state of emergency spurred by the presence of numerous "nomad settlements" in the regions of Latium, Lombardy and Campania. The ruling was motivated by the "massive invasion" of what in popular parlance, but also administrative labels, are commonly called "nomads": a heterogeneous group made of various Roma from ex-Yugoslavian countries, as well as from new EU member states (in particular Romania and Bulgaria), but also Italian Roma (including Sinti and Caminanti $^{2}$ ). The declaration of a state of emergency provided prefects with exceptional powers and resources to combat "nomad criminality". This episode, referred to as emergenza nomadi, was neither a real emergency - the declaration of a state of emergency being limited to natural catastrophes ${ }^{3}$ - nor about "nomads": most of the Roma and Sinti in Italy, like in most European countries, have been sedentary for at least three generations. A "fictitious state of emergency"4 declared by decree, the emergenza nomadi was ruled unconstitutional in November 2011.5 Yet, 10 years after the declaration, some of the structures and dynamics brought about by the emergency decree pursue unimpeded their insecuritization work in Rome's peripheries. The "Public and Emergency Security"

1 Piasere 2012. - I am thankful for their constructive comments to Maria Ketzmerick, Regina Kreide, Andreas Langenohl, and the participants of the concept group on power within the project SFB-Transregio 138 'Dynamics of Security. Types of Securitization in Historical Perspective', funded by the German Research Foundation. An earlier version was presented at the 14th EASA Biennial Conference "Anthropological legacies and human futures", 20-23 July 2016, Milan, Italy.

2 Travelers, in Sicilian.

3 Picker et al. 2015.

4 Agamben 2005, p. 3.

5 La Repubblica 2011. 
unit of the local police, set up in 2010 to control "nomad camps", is still operative, and the authorities are perpetuating the politics of eviction intensified with the emergency decree.

The declaration of the emergenza nomadi could be read as a paradigmatic case of what the Copenhagen School theorizes as "securitization": the performative speech act through which actors construct an existential threat dictating measures which take a particular issue from the circuit of politics into the realm of exceptionality. However, the Roma have long been subjected to securitarian measures in Italy, ${ }^{6}$ before the moment of the declaration of the emergenza nomadi, and the juxtaposition of the terms "emergency" and "Roma" is not a new speech act (see, for instance, L'Unità 1996). Hence, "securitizing moves"7 have been articulated before in local politics in Rome, and even though they did not amount to exceptional measures within a political-legal framework, the Roma have been placed, through "politics as usual", in exceptional spaces: camps. Instituted through a series of regional laws in the nineties, the camps are in many ways exceptional. Reserved to groups conceived as Roma, Gypsies ("zingari"), or "nomads", the camp originates in a logic of exception revealed by the very contradictions it inhabits. ${ }^{8}$ What the pre-existence of the camps means for the analysis of the emergenza nomadi as a successful securitization move is that its roots lie elsewhere than in its speech act: camps have acted as objects of (in)security since their beginning as spaces of exceptionality, already silently "doing" (in)security prior to the declaration. ${ }^{9}$

By bringing back together what are often conceived as different aspects of securitization - the speech act and the materiality of (in)security-I intend, in line with previous criticisms addressing the exclusive focus of the Copenhagen School on speech acts, to underline and illustrate the pertinence of thinking through materiality as constitutive of securitization. On the one hand, I wish to enter in a dialogue with critical security scholarship which has theoretically and methodologically engaged with the materiality of security, ${ }^{10}$ making use of the analytical tools of actor-network

6 Piasere 2009 and 2012; Coccia 2012.

7 Buzan et al. 1998.

8 These terms are largely interchangeable in popular use.

9 I choose to use the term (in)security as in Bigo's model of the Möbius ribbon in which security and insecurity are part of the same continuum (Bigo 2001).

10 Bourne 2012; Walters 2014; Aradau et al. 2015. 
theory. On the other hand, I attempt at enriching the debate by incorporating insights from a strand of anthropology which seeks to conceptually and methodologically destabilize the distinction between object and representation. This body of scholarship challenges the Cartesian dualism between mind and matter, between signifier and signified, between object and representation. Thus, instead of superimposing a supplementary, distinct focus on materiality in securitization, thereby reproducing the dualism between object and representation, I aim at collapsing this distinction, thinking through "things as meanings" 11 rather than "seeing" meanings behind things. This move obliges us to put securitization grounded in the speech act on its head, and contemplate not how words do things, ${ }^{12}$ but rather how things do words. ${ }^{13}$ Put differently, I am interested in exploring how a particular constellation of things - the camp and the objects around it- "does", through human-non-human associations, (in)security, in a manner disconnected from the speech act which declares it a dangerous object to be moved to a politics of exceptionality. This question transcends the division between discourse and materiality, which has recently been the focus of methodological reflection on critical security studies. ${ }^{14}$ It proposes to analytically and methodologically move past the distinction between things and the meanings of insecurity attached to them in various contexts, and explore how people and objects quietly fabricate insecurity in complex and unpredictable chains of associations.

This move opens up new terrain, both analytically and methodologically, and solves a considerable tension in the constructivist approach of critical security studies. It has been argued that this strand of scholarship conceptually ignores the affective dimension of insecurity grounded in fear, positing it as a dimension of irrationality affecting people manifestly incapable of understanding the very constructedness of their fears, and unable to brush them aside as mere mental creations. ${ }^{15}$ Thus, the constructivist interpretation of insecurity does not only posit that people have different "views" on the same reality - making security an issue of interpretationbut, underlined by implicit and often unexplored normativities, in the same move it orders those views in hierarchies of adequacy to the world

11 Henare et al. 2006.

12 Austin 1962.

13 Latour 2000.

14 Aradau et al. 2015.

15 Schwell 2015. 
"out there". Obviously, then, the analyst's construction of the world-its interpretation-is posited as superior to the "worldviews" of the people whose beliefs are relegated to mere irrationality and false consciousness. This, in turn, links to Latour's critique of critique itself: ${ }^{16}$ the analyst will always be right by the power she has to assign false consciousness to those whose views are in disagreement with her own. This analytical conundrum has become most obvious in the so-called Welsh School of critical security studies, which applies the constructivist approach only when deconstructing the insecurities claimed by some, while taking the security of others, in contrast, very seriously. For this strand of research, security is a very real matter, but of crucial importance is whose security is at stake. In this move, the insecurities of some are deemed morally justified and thus more "real" than the insecurities of others, taken to be prejudiced, generally powerful actors, using security instrumentally to oppress the dominated. Thus, the Welsh School distinguishes between "real-real" threats and "allegedly real" ones. ${ }^{17}$ The normative distinction between those entitled to speak of real insecurities and those whose insecurity is a mere construction seems to lie precisely in the dimension of power. Put differently, one could assess the truthfulness of their insecurities by considering whether actors have the power to shape the political security agenda, or whether they are powerless when facing the insecurities imposed, at their expense, by the powerful - and thus implicitly in need of emancipation. ${ }^{18}$ This position, however enticing it might be from the perspective of engaged scholarship, is simplistic and analytically untenable, for it applies the constructivist lens to some discourses, and the realist one to others; it can do so precisely because it maintains the distinction between reality and plural, yet normatively hierarchized representations of it. In turn, when this distinction is collapsed, following instead the chains of associations which produce particular worlds, one can avoid the apportioning of false consciousness to some, in a constructivist vein, while simultaneously taking the insecurity of others seriously, according to realist conceptions. Methodologically, it opens up the possibility of using world-making concepts closer and more adequate to the ones our interlocutors utilize to shape their own world. ${ }^{19}$

16 Latour 2004a.

17 Wæver 2004, p. 6.

18 Booth 1991, p. 319.

19 Henare et al. 2006, p. 16. 
When considering how the Roma in Rome are managed as threats, it would be facile to claim that their securitization is a social constructionalbeit with very concrete material consequences - and to attribute this dynamic to the workings of "power", on the one hand, and to racism, discrimination, and exclusion, on the other hand. But, although these are doubtlessly facets of what the Roma go through in their daily lives, such theorizing seems to quickly exhaust the possibilities of explanation and produce a circular account in which racism, discrimination and exclusion are the explanans, instead of the explanandum. Instead, I want to propose a much more complicated and blurred - but also conceptually richer-picture, in which objects play a paramount role in the story of how - and thus why - the Roma are managed through security technologies, measures, and policies. By resisting the division between things and their interpretation, I intend to show how insecurity is reassembled through chains of human and non-human actors; instead of separating insecurity from its own materiality and speaking of "perceptions" of insecurity, the theoretical and at once methodological parti pris is to use "conception" to refer to conceiving - bringing into being - insecurity in its materiality: "[c]onception is a mode of disclosure (of - metaphorical - 'vision') that creates its own objects, just because it is one and the same with them, so to 'see' these objects is to create them". ${ }^{20}$ Following the chains of associations in which different human and non-human agents act is aimed at retracing how these objects are created, from the perspective of those involved in thinking through things.

In the process, Roma camps become, from matters of fact - materiality requesting interpretation away from itself-complex matters of concern holding at once the materiality and its representations in one single "thing" around which a constellation of objects mediates complex negotiations between various actors, perpetually fabricating the camp and its inhabitants as ontologically dangerous. For Latour, matters of concern "have no clear boundaries, no well-defined essences, no sharp separation between their own hard kernel and their environment. It is because of this feature that they take on the aspect of tangled beings, forming rhizomes and networks. (...) Finally, and this may be the strangest thing of all, they can no longer be detached from the unexpected consequences that they

20 Henare et al. 2006, pp. 14-15. 
may trigger". ${ }^{21}$ In this resides, according to Latour, the proclivity of matters of concern to produce "crises"; no wonder, thus, that the crisis of the emergenza nomadi had to do with the proliferation of informal camps: they are matters of concern. Thus, in the Latourian move of "merging... matters of fact into highly complex, historically situated, richly diverse matters of concern", ${ }^{22}$ I divert attention from the conditions of possibility of Roma camps - in disconnection from their materiality - onto how this materiality is productive by entering into chains of associations. My argument is thus an exercise in an anthropology of security inspired by a Latourian sociology of associations, past its hitherto preoccupation of understanding the "local slippages" of "security" in its contexts (Goldstein 2016).

I will focus on two camps located in the Eastern periphery of Rome, introducing them as things ontologically fabricated as dangerous, around which several discursive and material practices of (in)securitization occur. I will mobilize the ethnographic material to explore the ways in which power works ambiguously through the materiality of the camp to (re)produce ontologically dangerous objects commanding security practices incrementally. ${ }^{23}$ In the process, I take the anthropological endeavour to be aimed at elucidating the (in)security logics of various actors on their own

21 Latour 2004b, p. 24.

22 Latour 2004a, p. 237.

23 The ethnographic material in which I ground my analysis has been gathered since 2014 from multiple sources, in a multi-sited ethnography (Marcus 1995) spanning not only different geographical places - two Roma camps and a police precinct in the Eastern periphery of Rome, as well as the two neighborhoods in which the camps are situated - but also the virtual space, as outside of traditional on-site fieldwork I conduct digital ethnography (Pink et al. 2015) on social media content produced and circulated by the two neighbourhood committees and by a neighbourhood patrol group. While such an approach has the disadvantage of dispersing my observation (Hannerz 2003), it has the incommensurable benefit of seeing the space of the camp from the multiple perspectives and layers which construct it both discursively and materially as a space of insecurity. My analysis draws upon participant observation carried out during police patrols around the two camps and during night patrols with the patrol group, upon police reports and correspondence between the local police and various institutions between 2010 and 2015 on matters regarding the two camps, as well as upon material (complaints, photographs, reports, e-mail communications) sent by the neighbourhood committees to the local administration (including the police). The digital ethnography is carried out on material posted on the Facebook page of the neighbourhood patrol group from 2013 onwards and by members of the neighbourhood committees. Additionally, I 
terms ${ }^{24}$ by retracing the associations through which they conceive the camp, as well as focusing on the lived experiences of (in)security 25 in their materiality. The collapse of the Cartesian dualism will enable a different type of analytical intake on the locus of power in securitization; in the process, the camp materiality becomes at once power to securitize and power of securitization. ${ }^{26}$

The chapter is articulated in three moves. First, I will shortly expose the history and ambiguities of the camp as technology of governing the Roma in Italy, and argue that the idea of nomadism as the essentialization of Romani culture acts as a mediator reconfiguring and reassembling Romanon-Roma sociality as a function of insecurity. Then, I will proceed to retrace the chains of various human and non-human actors fabricating the camp as a space of insecurity, demanding ever-escalating security measures. Finally, I will chart the ethnographic material's affordance to theorize power in reassembling (in)security.

\section{Roots of insecurity: The fixity of nomadism}

Initially part of a narrative of recognition and protection of cultural rights, the camps were intended as policy instruments granting temporary stopping places (campi sosta) to Roma, copied after the British and French legislation of the sixties aimed at Travellers and Gens $d u$ voyage. ${ }^{27}$ It is from this logic that campi sosta were advocated for by Opera Nomadi (Nomad Works), a Catholic church-based organization founded in the sixties and co-opted by the state in an expert role regarding "nomad" issues. The idea was highly ambiguous, pendulating between the logic of protecting Roma culture, whose hard and immutable kernel was considered to be nomadism, ${ }^{28}$ and the desire to restrict mobility by encouraging sedentarization through assistential projects aiming at building permanent ties

have carried out interviews with police officers and members of the neighbourhood committees, as well as with Roma from the two camps; I complement my material with newspaper articles from the local press from 1987 onwards.

24 Holbraad and Pedersen 2012: 166.

25 Maguire et al. 2014; Goldstein 2016.

26 See Langenohl, this volume.

27 Piasere 2006.

28 Sigona 2003 and 2005; Brazzoduro 2015; Tosi Cambini 2015. 
with the territory through schooling and incorporation in wage labour. ${ }^{29}$ Mobility was - and continues to be - seen as sign of inferiority ${ }^{30}$ and abjection, ${ }^{31}$ as well as danger, ${ }^{32}$ including in judicial proceedings, when arguments regarding the social dangerousness of Roma have been derived from their "condition of being nomadic". ${ }^{33}$ At the heart of these conceptions of mobility and the subsequent attempts of containment lies the potential of disruption stemming from an ethnocentric view of sedentary attachment to place, and the othering of Roma as "matter" perpetually out of place, hence dangerous. ${ }^{34}$

Scholars have analyzed the camps as technologies of (bio)politics through which the separation of the undesirables is effected in the urban space, with a large array of consequences: segregation, discrimination and the breakdown of social ties between camp insiders and the surrounding population. A result of an ambiguously romantic-cum-repressive projection of Italians, ${ }^{35}$ the camp is seen as the government technology to dominate the Roma through their bodies, a privileged contemporary instrument of power. ${ }^{36}$ The creation of camps as management instruments for the Roma is contemporaneous to the transition from an intellectual and political model of inclusive community, inspired by ideals of the social state, to a model of exclusive state, underscored by ideas of criminality control and repression. ${ }^{37}$ The emergence and multiplication of sizeable camps has been placed in the context of the global expansion of the state of exception $^{38}$ and, in the Italian case, as a development marking the convergence of policies aimed at managing the Roma and the repressive policies towards migrants..$^{39}$ The camp has been understood as the instrument through which the socio-economic problem of the discrimination of the Roma is reduced to a spatial problem, ${ }^{40}$ which is defined predominantly as

29 Daniele 2011, pp. 114-116; Picker et al. 2015, p. 747.

30 Piasere 2009.

31 Sigona 2003; Hepworth 2012.

32 Coccia 2012, p. 37.

33 Tosi Cambini 2011.

34 Douglas 1991.

35 Sigona 2005, p. 746.

36 Clough Marinaro 2009, p. 270; Tosi Cambini 2015.

37 Piasere 2006, p. 11.

38 Agamben 2005.

39 Bermann/Clough Marinaro 2011, p. 65.

40 Pusca 2010. 
a security and public order problem. ${ }^{41}$ Once the ethnographic magnifying glass is used, the ambiguous nature of the camp is revealed in the fact that it simultaneously offers protection, recognition and anonymity, rendering its inhabitants invisible while projecting them as a dangerous collective into public imagination. ${ }^{42}$ However, the agentic dimension of the materiality of the camp has largely been left out in these theorizations, leaving unaddressed the question as to how precisely the idea of nomadism has been so persistently and powerfully productive in fabricating the Roma as ontologically criminal subjects. The answer, I think, lies in the materiality of the camp.

Building on a Latourian sociology of associations ${ }^{43}$ in which mediators "transform, translate, distort, and modify the meaning or the elements they are supposed to carry", ${ }^{44}$ I argue that the idée fixe of nomadism became the main mediator in assembling the relations between Roma and non-Roma, altering the course of events in how the former were managed by the latter, both through material technologies (camps and the objects around them) and through policies (of surveillance, control, and repression). Nomadism is therefore more than a projected, reified mental representationor, as it has been argued, a powerful transcultural cognitive scheme, ${ }^{45}$ and a perennial institutional reference. ${ }^{46}$ It is a mediator with its own agency in the reassembling of Roma - non-Roma sociality as a function of (in)security. In practice, nomadism is at the root of the adoption, between 1984 and 1995, of a series of regional laws regarding the establishment of camps for "nomads", effecting the material technology of the camp, which subsequently gives way to a constellation of objects governing Romanon-Roma relations in the security key. Nomadism, embedded in the materiality of the camp, fabricates an ontologically criminal subject; as a police officer argued: "why would they want to be nomadic if they didn't want to run away from the state? A nomad doesn't have a residence place, an address, because he (sic) wants to escape. It must be that he has something to hide". ${ }^{47}$

41 Tosi Cambini 2015.

42 Sigona 2015.

43 Latour 1996 and 2005.

44 Latour 2005, p. 39.

45 Piasere 2009, p. 10.

46 Tosi Cambini 2015, p. 164.

47 Interview police officer, April 2016. 
Hosting about a quarter of the Roma and Sinti population in Italy, ${ }^{48}$ the camp is a label for a heterogeneous variety of settlements ranging from "equipped" or "authorized" camps - established by municipalities starting the 1980s, endowed with minimal (and often faulty) infrastructure - to "abusive" camps - informal settlements of recent Roma migrants from the new Eastern EU member states, made of autonomously built shacks. In between these two categories, a third ambiguous and volatile one refers to "tolerated" camps: generally established by groups of Roma in the margins of urban areas, but on land pertaining to municipalities, these camps are deemed to have been performatively recognized by the authorities by means of the introduction of basic material infrastructure-revealing yet again that one can do words (adding the label "tolerated" to a camp) with things (infrastructural improvements), and thus the agency of materiality in the politics of camp governance. In practice, the boundaries between these categories are porous. For instance, the camp of Tor de Cenci in the Southern periphery of Rome was downgraded from "authorized" to "tolerated", ${ }^{49}$ in order to facilitate and justify its dismantlement in September 2012.

Following the declaration of the emergenza nomadi, the Alemanno administration in Rome issued the "Plan for Nomads" (Piano Nomadi), detailing the steps to be undertaken under the emergency. Supported by the allocation of a substantial amount of financial resources in the name of emergency, the plan had a markedly spatial dimension, revolving emphatically around camps; the measures aimed at reducing the maximum number of "nomads" in Rome to 6,000 (whereas the estimates indicated their number at over 7,000), the displacement of people from "abusive" camps, the dismantlement of all informal settlements and of some of the "tolerated" camps, the restructuration of the existing "equipped" camps to receive new residents and the establishment of two new "villages" in which the administration would concentrate the remaining Roma. The administration initiated a spatial politics of evictions and displacements, in a movement of "degypsification of the Roman urbs" from inside the once symbolic and material border of the city - the city ring road - towards the peripheries. ${ }^{50}$ Through repeated evictions, some authors contend that the Roma were

48 Associazione 21 Luglio 2013.

49 Amnesty International 2010, p. 10.

50 Bermann and Clough Marinaro 2011. - Non-governmental sources indicate, for instance, that between 2013 and 2014, 88 evictions (involving approximately 
thus effectively "nomadized", 51 thus "regypsified" to fit the Gadjé (nonRoma) stereotype of mobility, ${ }^{52}$ suggesting that the camp does more than merely reflect a representation; it ontologically fabricates "gypsiness" and, with the criminalization of the Roma, insecurity.

Through the imaginary of nomadism and danger, and the subsequent stigma it produces, the camp has been analyzed as an apparatus, becoming agential in a "broken down" relationship; it would "[break] down direct social connections by reducing the ability of one individual to make a personal decision about another; to fathom what others experience; and to craft one's own representation of others". ${ }^{53}$ Thus, it precludes moral and political choices through the power it has to define its inhabitants prior to any real encounter. ${ }^{54}$ However, the actor-network theoretical lens on the materiality of the camp will illustrate how the relationship is not "broken down" as if it was pre-existent, but is mediated and continuously reassembled through particular deployments of associations, reassembling the Roma as producers of insecurity. The materiality of the camp is a particularly effective mediator in this work of reassembling.

\section{Reassembling (in)security: Networks of mediators}

Rather than purporting that the camp "reflects" or "incarnates" the relationship between Roma and various other actors, the approach I adopt in my argument underlines how the camp and the objects pertaining to it form chains of mediators, ${ }^{55}$ reassembling the management of the Roma in the securitarian register because they produce ontologically dangerous objects and people. This approach follows the more recent attention of critical security studies to materiality ${ }^{56}$ and aims at tracing the networks in which objects have agency in the co-production of (in)security. I will thus

2,400 persons) have been performed in Rome (Associazione 21 Luglio 2015). In these statistics, the same person may have been counted several times, as evictions led to the creation of other informal settlements which were subsequently evicted again.

51 Sigona 2003 and 2005.

52 Piasere 2009.

53 Feldman 2011, p. 390.

54 Diken and Laustsen 2005, p. 17.

55 Latour 1996, 2000 and 2005.

56 Walters 2014; Aradau et al. 2015; Green and Zurawski 2015; Meiches 2015. 
analyze the chains in which various human actors and diverse thingscamp fences and surveillance cameras in one of the camps, and waste and smoke in both - participate to perpetually reassemble the Roma-non-Roma interactions around the theme of (in)security.

Both camps are situated in the eastern periphery of Rome, with Salviati, unlike most other camps, ingrained in the urban tissue of the neighbourhood of Tor Sapienza, and Salone beyond the city ring road, in a scarcely inhabited area. Both camps are heavily overpopulated. Salviati hosts approximately 400 Roma descending from families that migrated in the seventies from Serbia and Bosnia; Salone, initially designed for 600 people, saw its numbers nearly double as a result of the transfer of Romanian, Bosnian, Montenegrin and Kosovar Roma from the Casilino 900 camp in 2010, which was effected by the politics of eviction initiated during the emergenza nomadi. Salone is now home to about 900 people; as with other camps, the fact that various already opposing groups of Roma were placed together only accrued the internal conflicts, which had material repercussions on the camp: instances of vandalism - like the destruction of containers, mostly by arson-took place as acts of revenge between groups. Currently, Salone hosts around 900 Roma but the number is diminishing. The politics of the administration - as explained by a police officer-is to curb its expansion by removing containers of families who leave the camp rather than assigning them to families evicted from elsewhere.

The materiality of camps and the agency of human actors intertwine in chains of mediators reassembling the camp, and with it, their Roma inhabitants as ontologically dangerous and ultimately ungovernable. I will trace the associations producing the ungovernability of the Roma in two of the human - non-human chains which I was able to observe during my fieldwork.

\section{Good fences make good neighbours}

The metal, human height fence surrounding the camp of Salone is a recurrent theme in the reports of the SPE police unit-a special "public and emergency security" unit set up in 2010, with the stated aim of controlling authorized Roma camps, and executing the evictions of informal camps ordered by the local authorities. Set up during the controversial and subsequently repelled legislation of the emergenza nomadi, the SPE could be 
seen as an ethnic police unit. ${ }^{57}$ The reports detailing patrolling operations around the camps show a continuous concern to restore the borders of the camp, purportedly for security reasons. Officers report that the fence is continuously punctured by the Roma for the purpose of creating alternative ways into the camp through which the control at the gate could be avoided. ${ }^{58}$ As Piasere asserts, ${ }^{59}$ the Roma camp has the sole logic of "putting a border between who inhabits it and the surrounding society", a logic translated in the security idiom traceable in police reports: "The iron fence which delimits the equipped Village of Salone is broken and missing in numerous parts of the camp, which allows anyone to enter into and exit from the Village, thus compromising the security of the camp itself'. ${ }^{60}$

For the police, the holes in the fence are proof that the camp inhabitants wish to escape control; yet, they ignore the logic ruling camp comings and goings. As many Roma explain, these acts are an effect of the inhabitants' search for facility, but also for privacy in their comings and goings: instead of longing the internal alley towards the end of the camp, they can use the makeshift entrances next to their containers to shorten their paths, while simultaneoulsy keeping their movements away from the intruding gaze of other inhabitants, thus bending the material space to create autonomy against the containment effects of the camp enclosure. For the police, the broken fence is simultaneously a crime and proof of criminality: if

57 The declaration of the emergenza nomadi decree as unconstitutional in 2011 did nothing to remove from its job description the task of dealing with the "nomads", in particular during operations of eviction mandated by the authorities. However, after 2011 it received the supplementary task of handling minor refugees in Rome, extending thus the "ethnic" specialization beyond the "nomads".

58 In 2011, the Alemanno administration has introduced in most of the authorised and tolerated camps an armed security guard service performed by a public utility company. The guards were present 24 hours a day and were hosted in a container placed at the entrance of camps. They were tasked with controlling the access to the camp and reporting to the police or other relevant institutions on events occurred inside the camp. In 2013, following the depletion of funding allocated through the emergenza nomadi, the service has been removed. The guards mediated the policing of the Roma: they were in permanent contact with the SPE police unit, sharing office space in Ponte di Nona and communicating on a daily basis reports on events occurred during their shifts. Following the removal of the service, the container used for the purpose was entirely vandalised and the structure has since been removed.

59 Piasere 2006, p. 12.

60 Police report, September 26, 2014. 
breaking the fence is an act of vandalism on public property, hence a crime, the holes punctured by camp inhabitants as an attempt to forge a more comfortable space of autonomy inside the camp are mediators in reassembling the Roma as delinquent. The materiality of the holes is thus experienced conceptually as criminality. ${ }^{61}$ The attention the fence receives in police reports reveals the ambiguity of its protection/containment function: instead of ensuring security for the insiders/outsiders of the camp, it fabricates camp inhabitants as producers of insecurity, creating a mechanism for "securing mobility and mobilizing security". ${ }^{62}$

At first sight, the thirty-two cameras placed on high poles all along the fence of the Salone camp embody the panopticon, suggesting that the moves of Roma inside the camp perimeter are under strict surveillance. However, police reports and their correspondence with the company responsible for the management of the recordings reveal that the images were almost never usable to identify perpetrators of vandalism inside the camps, either because of their low quality (blurred or too distant from the place of action), or because the cameras did not function at all, for months at a time. ${ }^{63}$ Yet, the images taken by the cameras, when functioning, were limited to a narrow space along the fence of the camp, testifying to the agency of the camp enclosure in the decision of emplacement of the cameras. This deeper scrutiny of how these cameras (do not) function reinforces the warning that "surveillance" should not be defined a priori as such. ${ }^{64}$ Although intended to function, the primary mode of the cameras' agency became performative rather than effective. The cameras speak a language meaning different things to different actors: outside observers will deduce that the Roma are legitimately and justifiably under control, attesting to the ontological fusion ${ }^{65}$ between Roma and criminality, danger, and insecurity. On the contrary, for activists and pro-Roma advocates, the cameras enter into a different chain of associations: they suggest the illegitimate and abusive treatment to which the Roma are subjected. The

61 Holbraad 2006.

62 Meiches 2015, p. 477.

63 Police correspondence to local administration September 15, 2011; Police report on problematic situations at the Salone camp, October-December 2012; Correspondence from Roma Universal Services to police October 1, 2011 and February 6, 2012.

64 Green/Zurawski 2015.

65 Holbraad/Pedersen 2012, p. 189. 
recurrent failure of the cameras, in turn, functions as a mediator in producing the "failure" of controlling the Roma, manufacturing among police officers a generalized feeling of impotence pervading all levels of the hierarchy of the SPE: the Roma cannot be contained and controlled, even by means of pervasive surveillance or by the materiality of the fence. Thus, the fences, the holes in them, and the cameras are incorporated by various actors to build the frames of their explanations, surrounding themselves with new resources ${ }^{66}$ which reassemble the Roma as dangerous and ungovernable.

\section{Smokescreens}

In the immediate outskirts of most of the large camps lie heaps of waste in various quantities. Discarded or broken furniture, domestic appliances, old clothes, broken toys and household objects, car carcasses and any of the smaller parts of all these objects, as well as debris from construction sites can be found surrounding the camp past the fences or walls. How waste is amassed in large quantities around camps is a matter of contention, and of arduous negotiations: for some, it is the sign of a cultural propensity of the Roma to produce rubbish and live amidst it, incarnating what Piasere called the "peoples of landfills". ${ }^{67}$ Rubbish reproduces social hierarchies, becoming the mediator of the reification of the Roma as abject; the disposability of waste is extended to the Roma, often referred to as "the scum of society" (la feccia della società). However, a recent journalistic investigation $^{68}$ has revealed an entire chain of shady, often mafia-related practices of refuse management in which bulky detritus from construction sites is dumped near camps or given to the Roma instead of being transported to special sites. Domestic debris is given to Roma by private individuals or small firms, for considerably less money and effort than what is requested by special facilities to process them - the so-called "ecologic islands", where bureaucratic regulations make the process complicated, tiresome and expensive. ${ }^{69}$

66 Latour 1996, p. 12.

67 Piasere 2005, p. 160.

68 Belli et al. 2015.

69 I have described more in detail elsewhere (Ivasiuc 2019) how waste is used in visualisations circulated on social media by the neighbourhood patrol of Ponte di Nona, leading to the fabrication of the Roma as producers of insecurity in a pro- 
Waste is recurrent in Facebook posts of the neighbourhood committees of inhabitants in the camps' surroundings, as well as on the social media page of a group of citizens from Ponte di Nona, who carry out night patrols in order to protect their neighbourhood of crime against property. The latter also share large quantities of visual material on social media. ${ }^{70}$ In their accounts, waste is a powerful agent: it has the power to transform a neighbourhood from a middle-class habitat worthy of investment into a decayed urban periphery. Waste abounds also in police reports signaling "a severe situation of socio-environmental decay" in camps. ${ }^{71}$ The accumulation of waste becomes a cultural marker for the Roma: "Such ethnic groups persist in the traffic of abusively collected waste from construction sites, companies and private individuals, discharging the refuse either inside the camp or on the neighbouring streets" (my emphasis). ${ }^{72}$ The public sanitation services rarely collect waste accumulated near camps, and only on demand and using extraordinary means, generally through subcontracts to other firms. ${ }^{73}$ This, in turn, leads to the practice around which most anti-Roma discourse is structured nowadays in Rome: the combustion of remnants of waste around the camps.

The causes of the fires are ambivalent and multiple, and their initiators are almost never caught. One of the reasons for the arson of certain types of material is their treatment for the separation of metals: typically, the copper and other rare metals inside electric cables are obtained by burning the plastic insulation around. When the police investigates the origin of fires, inhabitants remain silent and profess their ignorance as to who is responsible for them. Their silence facilitates the articulation of hypotheses on low-intensity conflict between the Roma and the police: "It is hypothe-

cess of naturalization of social hierarchies, based on "social sorting" (Lyon 2003) between providers of security and producers of insecurity.

70 Ivasiuc 2015 and 2019.

71 Police reports September 15, 2011 (Salone); March 28, 2012 (Salviati); January 10, 2013 (Salone); November 30, 2013 (Salviati).

72 Police report, March 8, 2012 (Salviati).

73 Subcontracting services by the direct attribution of contracts and the use of public funds are the mechanisms used in profit-making schemes which have recently amounted to the scandal of Mafia Capitale. Irrupted in November 2014, the scandal revealed a network of corrupted public servants and their clients (either private firms or non-governmental entities) involved in service provision towards refugee and immigrant centres, as well as Roma camps. 
sized that the fire may have been caused by the village ${ }^{74}$ guests as retaliation to the previously performed police activity" (institution of the parking prohibition for vans, n.a.) ${ }^{75}$ Another police report states that the fire was "presumably a form of protest against the dispositions of the municipal authorities". ${ }^{76}$ In another instance, a camp inhabitant suggests that a recent fire may have been started by the families who had been evicted from the camp on grounds of their generous bank accounts. ${ }^{77}$ These instances commend a political reading of the phenomenon of fires, similar to Kerry Ryan Chance's approach in the case of a shack settlement in Durban where the inhabitants systematically provoke fire, coming to "inhabit political roles"; 78 using fire as a means to redirect power, the Roma become legible to state agents as ungovernable.

The smoke resulting from the combustion of waste has come to lie at the centre of securitarian discourses on the campi nomadi in Rome, taking precedence over concerns of petty criminality. The discourses woven around this practice refer predominantly to health-related concerns about the inhalation of dioxin from the pyres, or to environmental concerns about soil and water pollution following the infiltration of burnt substances into the ground. Dioxin, in the Italian imaginary, is a powerful mediator ingrained in the collective memory of the 1976 industrial accident of Seveso, and is invested in negotiations around the danger produced by smoke around the camps with new force. Occasionally, the neighbourhood committees appear in the local press, requesting the intervention of the army: "It is difficult to say this, because it's a measure that goes against the logic of democratic life, but the only solution possible at this point is the intervention of the army to guard the area". ${ }^{79}$ In May 2015, one of the neighbourhood committees posts on social media a request to the Prefect of Rome requesting "to militarise the TERRITORY or it won't go well (...), intervene immediately or the citizens will take things in their own

74 The authorized camps are ironically called "villages of solidarity".

75 Police report July 4, 2014 (Salone).

76 Police report February 18, 2015.

77 Interview E., Salone, November 2014.

78 Chance 2015 , p. 396.

79 'Roghi tossici nel campo rom Salviati, il Cdq Tor Sapienza chiede invio dell'Esercito' [Toxic fires in the Roma camp Salviati, the neighbourhood committee requests the intervention of the Army]. May 26, 2015, http://www.municipioroma.it/ roghi-tossici-nel-campo-rom-salviati-il-cdq-tor-sapienza-chiede-invio-dellesercito/, retrieved May 26, 2015. 
hands. (...) This is not BLACKMAIL, but legitimate DEFENSE!" 80 The leitmotif of the exasperation of citizens which will soon push them to "take things in their own hands" is recurrent also in the discourse of the neighbourhood patrol, who yearly organizes protests as "ultimatums" addressed to authorities requesting the closure of the camps.

The neighbourhood committees and the patrol from Ponte di Nona often post images of smoke, with comments often referring to the neighbourhood as "under siege": "It is appropriate to use the army, because this is a zone of war. These are the chemical weapons used". ${ }^{81}$ These messages provide the context for their digital audiences to post comments containing hate speech or inciting violence towards the Roma, typically revolving around the leitmotif of "burn[ing] the camps with everyone inside". These photographs and the comments around them create acceptance towards suggestions to burn the camps down, as such comments systematically receive "likes" (Ivasiuc 2019). In the process, security is implicitly conceived of as the annihilation of the ones producing insecurity by means of smoke. Smoke produces identities on both sides: whereas the Roma are further criminalized, the politics of the neighbourhood committees produce a common victimhood identity mobilized in claims for military protection.

The smoke, its visualizations posted on social media, and the discussions around the risks associated with inhaling dioxin create social alarm and discontent to the point that the authorities, following the lobby of neighbourhood committees, started organizing, at the suggestion of the SPE, police patrols around some of the camps, precisely to control the fires. ${ }^{82}$ The intent of the police to prevent fires precludes a judgment regarding their different types and functions. For instance, during one of the patrols in December 2015, I witnessed the police requesting a family at Salone to put off a fire they had lit to cook dinner outside their container; on a different patrol at Salviati, on a winter evening after nightfall, policemen asked a group of men to put off a wood fire they had lit in a metal barrel to warm themselves up while socializing around it. Pro-Roma ac-

80 Facebook post, May 27, 2015, author's translation, capital letters in original.

81 Facebook comment by SV, May 27, 2015.

82 Police correspondence to local administration, October 30, 2014: the commander of the SPE requests the local police to institute a fixed surveillance service (servizio di vigilanza fissa), "given the protests of citizens regarding the toxic smoke derived from waste burning”. 
tivists report that some of the smoke comes from the heaters inside the containers, which produce the same amount of alarm among neighbours as the pyres of waste.

Policing different fires is not a practice performed in undifferentiated ways. Because of the high demand of staff and resources that the continuous surveillance service around the camps requires, the SPE has requested the participation of all local police units in the process. This has lead to internal conflicts and struggles between various police units and between agents and their superiors; in these struggles, the labour conditions around the camps are securitized, as police agents contest the decision: "at the site in which the surveillance was carried out there is presumably toxic smoke due to the combustion of braziers inside the shacks and containers of the camp. Moreover there is a substantial quantity of garbage on the side of the street, which makes the environment insalubrious". ${ }^{83}$ Many agents are reluctant to spend hours on end in a service that is deemed difficult and dangerous, but also worthless and stigmatized: there is something like a social division of police labour in which the SPE, considered the "Gypsies' police", is seen as carrying out labour inferior to other police work.

In practice, various patrol teams carry out the surveillance service with varying degrees of involvement: whereas some teams jump at the sight of any quantity of smoke, demanding that any fire be put off, some other teams do not intervene at all, even when smoke is visible inside the camp. When the police alert the firemen regarding an incipient waste fire, they are sometimes met with their refusal to intervene until the fire becomes more powerful, or with delays which sometimes lead to the extension of the fire. The neighbourhood committees have picked up on the inefficiency of the surveillance service. For example, on Facebook, on a photograph of smoke rising from the camp of Salviati, a member of the neighbourhood committee from Tor Sapienza highlights the police car parked outside, at a considerable distance from the camp entrance, to suggest the inability of the police to control the fires. Members of both neighbourhood committees often engage in accusations that the police are not efficient in protecting them from smoke, reproducing narratives of citizens soon "pushed to take things in their own hands". The inefficiency of the continuous surveillance service strengthens a discourse articulating the impo-

83 The text was repeated in several police reports, accusing current regulations for the lack of conformity of these particular labour conditions. 


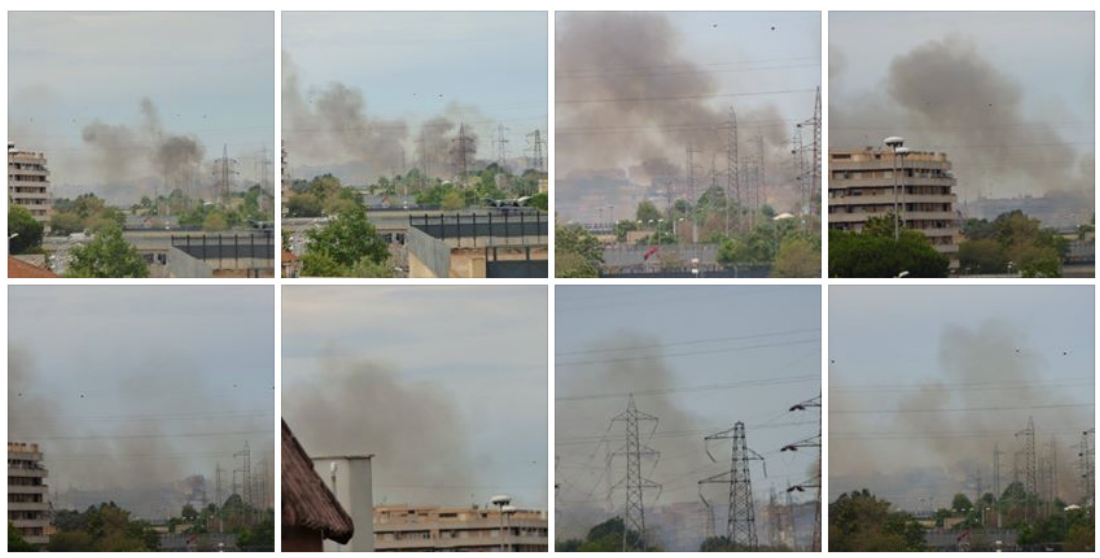

Image 1. Photographs of smoke posted by a member of the neighbourhood committee of Tor Sapienza (15.07.2016). Source: Facebook

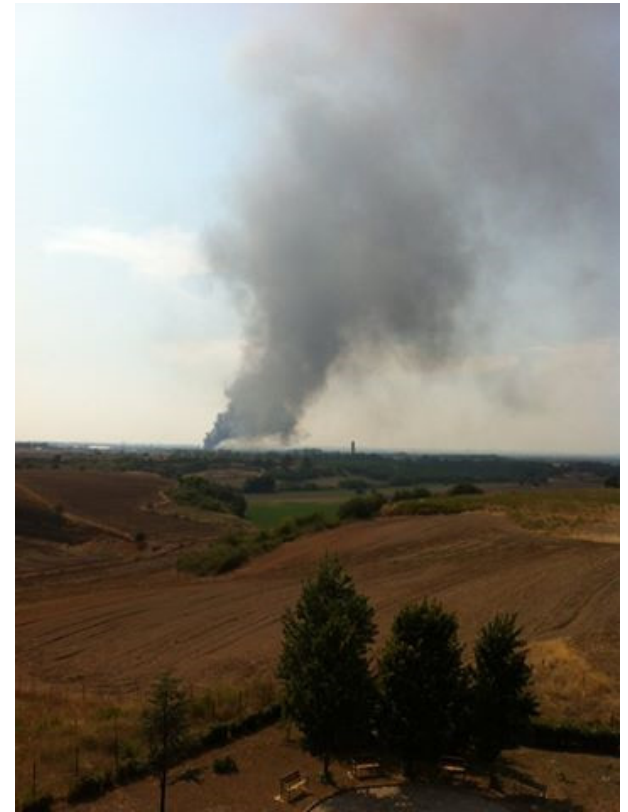

Image 2. Photograph of smoke posted by the neighbourhood patrol of Ponte di Nona (August 8, 2015). Source: Facebook 
tence of the police to tackle the problem with a pre-existing narrative of abandonment by the institutions; ${ }^{84}$ all the while, the inhabitants of peripheral neighborhoods produce self-victimized identities while criminalizing the Roma.

\section{The power of materiality and the materiality of power}

Within critical security studies, power has been studied in rather unsystematic ways, and, first and foremost, the power of the securitizing elites and the impact of securitization on power relations have constituted points of scholarly interest; ${ }^{85}$ at the same time, attention to the materiality of securitization is relatively recent. This gap invites reflection on the power of materiality, and the materiality of power in securitization.

Tapping into the potential of the actor-network perspective, I have showed how objects are mobilized by various actors to make certain securitizing moves, in a maze of discursive and material practices spanning a field of negotiations; the space of the camp has become associations ${ }^{86}$ which render the Roma as producers of insecurity. As we have seen, the camp plays a consequential, highly ambiguous role. Conceived as a technology of threat containment, the camp, together with its materiality, simultaneously fabricates and perpetuates the very danger it purports to contain, by entering into powerful associations which produce an ever growing demand for more security, and more policing. If the fence is there to contain - and, although ambiguously, also to protect - the camp inhabitants, the holes they puncture in the fence associate with police in chains which cast the Roma as ontologically criminal, uncontainable and ungovernable. The objects making up the waste around the camps associate in complex networks with the regulations of "ecological islands", company staff and individuals seeking to minimize the costs of discarding bulky refuse, the money given to the Roma in exchange for disposing of these objects, the public sanitation company not serving the areas around the camp, the fear for falling real estate prices in "decaying" neighborhoods, and the material posted by the patrol and the neighbourhood committees on social media. Smoke from the pyres of rubbish, in turn, associates with

84 Quassoli 2004.

85 Balzacq 2011; Balzacq et al. 2015; see also Langenohl, this volume.

86 Latour 1996. 
neighbourhood committees and their securitizing moves, the visual and textual material posted on social media, the technology of the Facebook interface allowing for the co-production of speeches and images, the authorities ordering police patrols, the SPE, safety labour regulations, other police units and so on, producing every time anew the camp and its inhabitants as dangers demanding security measures.

The incorporation of the materiality of the camp and the ways in which objects are used in the production of insecurity allowed for the increased focus on forms of agency which often remain invisible in accounts on Roma camps which do not take the power of the camp materiality fully into account. Often, more shallow perspectives adopt dichotomies between the dominant and the subordinate, whose agencies seem confined to the predetermined roles of the "powerful" against the "powerless". However, the material elasticity of the camp ${ }^{87}$ allows for the Roma to exert some forms of (what is commonly assumed to be) "power" on the concrete ways in which they are contained by the enclosure of the camp and the attempts to enact surveillance: breaking the fences in what seems to be a continuous "guerrilla" with the police, acts of vandalism on containers and cameras exerted in response to surveillance measures, and the continuous practice of manifestly uncontrollable fires. On the other hand, all too often police control, surveillance, and repression are conceptualized as totalizing repressive power. My argument allows nuance in this debate, as the police often prove "powerless" in front of the phenomena with whose containment they are entrusted. This account helps revisit familiar assumptions about power, and allows for the conceptualization of its locus in securitization.

The concept of power is, for Latour, "a pliable and empty term" used uncritically to "explain (away) hierarchy, obedience or hegemony", which, he argues, social scientists would do better to do away with; it allows a shortcut precluding the actual work of explaining. He subsequently proposes a model of translation to account for the circulation of "claims, orders, artefacts, goods" through chains made of multiple agents acting on the "token" that is to be transmitted - in our case, insecurity. In such a transmission, there is no inertia attributable to an abstract concept of power; rather, the translation is the consequence of the "energy" with which every actor invests the token, energy which is impossible to hold on to: it 
is immediately reinvested in the chain. The transmission finds new impetus as the actors find new sources of energy. In the process, actors mold the token to suit their interests, transforming it and passing it along to others, who in turn change it and shape it anew.

Conceptually, the chains of camp inhabitants, the objects they manipulate, and the conceptions they engender among residents, the neighbourhood patrol, and the police, are new, hybrid objects, reassembling insecurity through their complex associations. In the process, they become the power to securitize. Power is not possessed, but exerted, requiring its conceptual treatment as a consequence, rather than a cause of action (Latour 1984). Thus, power is not the cause of securitization moves, as securitization scholarship would have it, but its consequence. A long chain of mediators work together towards ever greater securitizing moves, and an ever more impending threat of violence on Roma camps. To claim that the neighbourhood committees or the patrol group have the power to securitize would ignore the work of smoke, the SPE, and the multitude of other associations which produced the institution of camp patrols to police fires. And even when this particular securitizing move has succeeded in enacting exceptional measures, can it really be said that the neighbourhood committees have power, given the inefficient policing of the pyres? The power to securitize, rather than being held by powerful actors, is contained in the entire chain of associations resting on the materiality of the camp. Power, then, becomes material.

The conceptual exercise I have proposed is to apply Latour's model of translation to the theorization of securitization in a model in which materiality plays at least as important a role as the agency of the humans forming the chains along which passes the ever-transforming insecurity with which the Roma are endowed. Thus, the Roma are perpetually produced as dangerous, thus in need of security measures and policies, through the agency of the complex and shifting chains of human and non-human actants translating "insecurity" with the fresh resources provided at each step in the chain: the camp, the holes in the fence, the surveillance cameras, the acts of vandalism perpetrated in retaliation within the camp, the waste, the smoke - and the dioxin in it - the photographs of smoke on social media, the police patrols, the neighbourhood committees, the SPE, labour safety regulations, and onwards and sideways to a multitude of other actants. In the process, power is not something either possessed, or exerted by "powerful" actors, but collectively exerted through chains of associations linked to the materiality of the camp itself. 
Some will perhaps argue that the argument is attempting to dissolve racism, diffusing - and defusing — it through objects devoid of intentionality. The discussion about this particular politics of explanation is intricate and beyond the scope of this chapter; however, the analytical choice of positing the racism and discrimination with which Roma deal in their concrete lives not as explanans, but as explanandum, also means that to refer to it in the explanation would render the argument circular.

There is, perhaps, a promising escape from securitization: the chain of translation may be interrupted at any point, should the token be dropped. A politics of altering the materiality of the camp would probably open up a path out of the incremental securitization of the Roma in Rome. And this had better happen before the humans entering the securitization chains acquire new resources to enact the promise of burning down the camp.

\section{References}

Agamben, Giorgio (2005): State of Exception. Chicago: Chicago University Press.

Amnesty International (2010): La risposta sbagliata: Italia: il "piano nomadi" viola il diritto all'alloggio dei Rom a Roma [The wrong response: Italy: the 'nomad plan' violates the housing right of the Roma in Rome]. Rome: Amnesty International.

Aradau, Claudia/Coward, Martin/Herschinger, Eva/Thomas, Owen D./Voelkner, Nadine (2015): Discourse/Materiality. In: Claudia Aradau/Jef Huysmans/Andrew Neal/Nadine Voelkner (eds.): Critical Security Methods: New Frameworks for Analysis. London \& New York: Routledge, pp. 57-84.

Associazione 21 Luglio (2013): Figli dei "campi": Libro bianco sulla condizione dell'infanzia rom in emergenza abitativa in Italia [Sons of "camps": White book on the condition of Roma children in housing emergency in Italy]. Rome: Associazione 21 Luglio Onlus.

Associazione 21 Luglio (2015): Peccato Capitale: Briefing sugli sgomberi forzati di comunità rom a Roma in prossimità del Giubileo della Misericordia [Capital sin: Briefing on the forced evictions of Roma communities in Rome around the Jubilee of Mercy]. Rome: Associazione 21 Luglio Onlus.

Austin, John L. (1962): How to Do Things with Words. Oxford: Clarendon Press.

Balzacq, Thierry (2011): A theory of securitization: Origins, core assumptions, and variants. In: Thierry Balzacq (ed.): Securitization Theory: How Security Problems Emerge and Dissolve. London \& New York: Routledge, pp. 1-30.

Balzacq, Thierry/Léonard, Sarah/Ruzicka, Jan (2015): "Securitization” revisited: Theory and cases. International Relations 30(4): 57-84. DOI: $10.1177 / 0047117815596590$. 
Belli, Edoardo/Granata, Rossella/Risi, Elena/Vivona, Valentina (2015): A Ferro e Fuoco: Fumi tossici nella "città eterna" [To Fire and Sword: Toxic smoke in the "eternal city"]. Rome: Kogoi.

Bermann, Karen/Clough Marinaro, Isabella (2011): Exclusivity and exclusion: Roma camps and the "degypsification" of the Roman urbs. Public: Art, Culture, Ideas 43: $62-75$.

Bigo, Didier (2001): The Möbius Ribbon of internal and external security(ies). In: Mathias Albert/David Jacobson/Yosef Lepid (eds.): Identities, Borders, Order: Rethinking International Relations Theory. Minneapolis: University of Minnesota Press, pp. 91-116.

Booth, Ken. 1991. Security and emancipation. Review of International Studies 17(4): 313-326. http://www.jstor.org/stable/20097269.

Bourne, Mike (2012): Guns don't kill people, cyborgs do: A Latourian provocation for transformatory arms control and disarmament, Global Change, Peace \& Security (formerly Pacifica Review: Peace, Security \& Global Change) 24(1): 141-163, DOI: 10.1080/14781158.2012.641279.

Brazzoduro, Marco (2015): Prefazione: Un'etnia senza un volto e senza una voce [Foreword: An ethnic group without a face and without a voice]. In: Adriana Goni Mazzitelli (ed.): Vincere il confine [Overcoming the border]. Rome: Aracne, pp. 14-17.

Buzan, Barry/Wæver, Ole/de Wilde, Jaap (1998): Security: A New Framework for Analysis. Boulder (CO): Lynne Rienner.

Chance, Kerry Ryan (2015): Where there is fire there is politics: Ungovernability and material life in urban South Africa. Cultural Anthropology 30(3): 394-423.

Clough Marinaro, Isabella (2003): Integration or marginalisation? The failures of social policy for the Roma in Rome. Modern Italy 8(2): 203-18.

Clough Marinaro, Isabella (2009): Between surveillance and exile: Biopolitics and the Roma in Italy. Bulletin of Italian Politics 1(2): 265-87.

Coccia, Benedetto (ed.) (2012): 'Zingari': Storia dei nomadi a Roma tra accoglienza e rifiuto ['Gypsies': The history of the nomads in Rome between reception and rejection]. Rome: Apes.

Daniele, Ulderico (2011): Sono del campo e vengo dall'India: Etnografia di una collettività rom ridislocata. Rome: Meti.

Diken, Bülent/Bagge Laustsen, Carsten (2005): The Culture of Exception: Sociology Facing the Camp. London: Routledge.

Douglas, Mary (1991[1966]): Purity and Danger: An Analysis of the Concepts of Pollution and Taboo. London \& New York: Routledge.

Feldman, Gregory (2011): If ethnography is more than participant observation, then relations are more than connections: The case for nonlocal ethnography in a world of apparatuses. Anthropological Theory 10(4): 375-395.

Goldstein, Daniel (2016): Some thoughts on the critical anthropology of security. Etnofoor 28(1): 147-152. http://www.jstor.org/stable/43823948.

Green, Nicola/Zurawski, Nils (2015): Surveillance and ethnography: Researching surveillance as everyday life. Surveillance \& Society 13(1): 27-43. 
Hannerz, Ulf (2003): Being there... and there... and there: Reflections on multi-site ethnography. Ethnography 4(2): 201-216.

Henare, Amiria/Holbraad, Martin/Wastell, Sari (eds.) (2006): Thinking through Things: Theorising Artefacts Ethnographically. London and New York: Routledge.

Hepworth, Karen (2012): Abject citizens: Italian 'nomad emergencies' and the deportability of Romanian Roma. Citizenship Studies 16(3-4): 431-449.

Holbraad, Martin (2006): The power of powder. In: Amiria Henare/Martin Holbraad/ Sari Wastell (eds.): Thinking through Things: Theorising Artefacts Ethnographically. London and New York: Routledge, pp. 189-225.

Holbraad, Martin/Pedersen, Morten Axel (2012): Revolutionary securitization: An anthropological extension of securitization theory. International Theory 4(2): 165197.

Ivasiuc, Ana (2015): Watching over the neighbourhood: Vigilante discourses and practices in the Suburbs of Rome. Etnofoor 27(2): 53-72.

Ivasiuc, Ana (2019): Sharing the insecure sensible: the circulation of images of Roma on social media. In. Huub van Baar/Ana Ivasiuc/Regina Kreide (eds.): The Securitization of the Roma in Europe. London/New York: Palgrave Macmillan, pp. 233259.

Latour, Bruno (1984): The powers of association. The Sociological Review 32: 264280. doi: 10.1111/j.1467-954X.1984.tb00115.x.

Latour, Bruno (1996): On actor-network theory: A few clarifications plus more than a few complications. Soziale Welt 47(4): 369-381.

Latour, Bruno (2000): The Berlin Key or How to do words with whings. In: Paul Graves-Brown (ed.): Matter, Materiality and Modern Culture. London/New York: Routledge, pp. 10-21.

Latour, Bruno (2004a): Why has critique run out of steam? From matters of fact to matters of concern. Critical Inquiry 30(2): 225-248.

Latour, Bruno (2004b): Politics of Nature: How to Bring Science into Democracy. Translated by Catherine Porter. Cambridge (MA)/London: Harvard University Press.

Latour, Bruno (2005): Reassembling the Social. An Introduction to Actor-Network Theory. Oxford/New York: Oxford University Press.

Lyon, David (ed.) (2003): Surveillance as Social Sorting: Privacy, Risk and Digital Discrimination. London/New York: Routledge.

Maguire, Mark/Frois, Catarina/Zurawski, Nils (2014): Introduction: The anthropology of security: Prospects, retrospects and aims. In: Mark Maguire/Catarina Frois/Nils Zurawski (eds.): The Anthropology of Security. London: Palgrave, pp. 1-23.

Marcus, George E. (1995): Ethnography in/of the world system: The emergence of multi-sited ethnography. Annual Review of Anthropology 24(1): 95-117.

Meiches, Benjamin (2015): A Political Ecology of the Camp. Security Dialogue 46(5): 476-492.

Piasere, Leonardo (2005 [1991]): Popoli delle discariche [Peoples of landfills]. Rome: CISU. 
Piasere, Leonardo (2006): Che cos'è un campo nomadi [What is a nomad camp]? Achab VIII: 8-16.

Piasere, Leonardo (2009[2004]): I Rom d'Europa: una storia moderna [The Roma of Europe: a modern history]. Rome and Bari: Laterza.

Piasere, Leonardo (2012): Scenari dell'antiziganismo: Tra Europa e Italia, tra antropologia e politica [Scenarios of anti-Gypsyism: Between Europe and Italy, between anthropology and politics]. Florence: Seid Editori.

Picker, Giovanni/Greenfields, Margaret/Smith, David (2015): Colonial refractions: The "gypsy camp" as a spatio-racial political technology. City 19(5): 741-752. DOI: 10.1080/13604813.2015.1071123.

Pusca, Anca M. (2010): “The Roma problem” in the EU: Nomadism, (in)visible architectures and violence. Borderlands 9(2): 1-17.

Quassoli, Fabio (2004): Making the neighbourhood safer: Social alarm, police practices and immigrant exclusion in Italy. Journal of Ethnic and Migration Studies 30(6): 1163-81.

La Repubblica (2011): “Piano nomadi, non c'era l'emergenza. Il Consiglio di Stato cancella il commissario" [Plan for nomads: there was no emergency. The Council of State revokes the commissary]. La Repubblica, 22 November 2011, available at http://ricerca.repubblica.it/repubblica/archivio/repubblica/2011/11/22/piano-nomadi-non-era-emergenza.html, retrieved July 15, 2016.

Schwell, Alexandra (2015): The security-fear nexus: Some theoretical and methodological explorations into a missing link. Etnofoor 27(2): 95-112.

Sigona, Nando (2002): Figli del ghetto: Gli italiani, i campi nomadi e l'invenzione degli "zingari". Civezzano: Nonluoghi Libere Edizioni.

Sigona, Nando (2003): How can a 'nomad' be a 'refugee'? Kosovo Roma and labelling policy in Italy. Sociology 37(1): 69-79.

Sigona, Nando (2005): Locating "the Gypsy problem": The Roma in Italy: Stereotyping, labelling and 'nomad camps'. Journal of Ethnic and Migration Studies 31(4): 741-756.

Sigona, Nando (2015): Campzenship: Reimagining the camp as a social and political space. Citizenship Studies 19(1): 1-15. DOI: 10.1080/13621025.2014.937643.

Tosi Cambini, Sabrina (2011): The social dangerousness of the defendant is "at one with her own condition of being nomadic": Roma and Sinti in Italian courts of law. Journal of Modern Italian Studies 16(5): 652-666.

Tosi Cambini, Sabrina (2015): Lo spazio del razzismo: Il trattamento dei corpi (degli) altri nel governo della città [The space of racism: the treatment of other(s') bodies in urban governance]. In Gaia Giuliani (ed.): Il colore della nazione [The colour of the nation]. Milan: Mondadori.

L'Unità (1996): 'Emergenza Rom, è scontro' [Roma Emergency, there is disagreement]. L'Unità, January 11, 1996.

Walters, William (2014): Drone strikes, dingpolitik and beyond: Furthering the debate on materiality and security. Security Dialogue 45(2): 101-118. 
Wæver, Ole (2004): Aberystwyth, Paris, Copenhagen. New "Schools" in Security Theory and their Origins between Core and Periphery. Paper presented at the annual meeting of the International Studies Association, Montreal, March 17-20. 